\title{
Can Federalism Save India's Constitutional Democracy?
}

\author{
Sujit Choudhry ${ }^{1} \mathbb{0}$
}

Accepted: 22 December 2021 / Published online: 2 February 2022

(c) The Author(s) 2022

\begin{abstract}
Madhav Khosla's brilliant book, India's Founding Moment, is self-consciously a work on the history of ideas. Nonetheless, the subtitle of India's Founding Moment-The Constitution of a Most Surprising Democracy-implies that Khosla draws a connection between the ideas that shaped the creation of constitutional democracy in India and its endurance. In this review, I pose the question of whether the design of the Constitution can be a source of constitutional resilience against the rising threat of authoritarianism and Hindu majoritarianism.
\end{abstract}

Keywords India $\cdot$ Constitution $\cdot$ Federalism $\cdot$ Political party

Madhav Khosla's brilliant book, India's Founding Moment, is self-consciously a work on the history of ideas. As Khosla puts it, India's Founding Moment is "a study of certain traditions of thought about democracy and constitutionalism at the moment of India's creation" (at 24) — that is, "the founding approach toward democratization" (19). His concern is not "with the working of Indian democracy" but "rather ... the decision to be democratic." India's poverty, illiteracy, and staggering diversity - combined with the necessity of adopting both constitutionalism and democracy simultaneously and instantaneously_made the success of constitutional democracy extremely unlikely. Why it has endured is a question answered by "historical studies of India's postcolonial life" (18) and scholarship in political science that has "investigated the inexplicable survival of Indian democracy" (18) in the absence of the cultural, economic, and social preconditions prevailing in Western Europe and North America, i.e., "the missing foundations on which self-government was widely thought to be predicated" (3) as well as the historical sequencing of

Thanks to John Ferejohn, Michaela Hailbronner, Sam Issacharoff, and Mark Tushnet for helpful comments.

Sujit Choudhry

choudhry@wzb.eu; suj@choudhry.law

1 WZB Berlin Social Centre, Berlin, Germany 
constitutionalism followed by democracy through the gradual expansion of the suffrage. This is not Khosla's project.

Nonetheless, the subtitle of India's Founding Moment-The Constitution of a Most Surprising Democracy-implies that Khosla draws a connection between the ideas that shaped the creation of constitutional democracy in India and its endurance. Indeed, the publication of India's Founding Moment coincided with a period of unprecedented strain for India's constitutional democracy. Khosla has been a brave voice in these debates, writing for global audiences in The Guardian, Time, The Atlantic, Foreign Affairs, and The Journal of Democracy to criticize the decisions that Prime Minister Narendra Modi's Bhartiya Janata Party (BJP) government has taken to erode and dismantle the founding vision of India's constitutional democracy, after its landslide re-election victory in May 2019. ${ }^{1}$ For Khosla, the two central pillars of the post-2019 Modi agenda are the Citizenship (Amendment) Act (CAA), which would offer citizenship to non-Muslims from neighboring countries fleeing persecution but not to Muslims, and the repeal of Article 370 of the Indian Constitution, which guaranteed the special autonomy of Muslim-majority Jammu and Kashmir. He shares the fear of many that these measures will be followed by others that will lead to the gradual replacement of India's secular democracy with a regime of electoral authoritarianism and Hindu majoritarianism.

For Khosla, it is significant that the Constitution has played a role in the resistance to Modi. Protests against the CAA often featured the assembled reading the preamble to the Constitution, which defines India as a secular state. Khosla calls this role "symbolic," but surely he would agree that this understates the role of the Constitution in these contexts. As Khosla insightfully argues in India's Founding Moment, the Constitution codified a constitutional morality, that created a shared frame of reference for political discourse in a new constitutional democracy. The anti-CAA protests, invoking the preamble, show how the constitution has provided a platform for political mobilization in its own defense by serving as a coordinating device, thereby enabling a constitutional practice of self-enforcement.

But I want to pose a different question, motivated by Khosla's own public interventions on the contemporary state of Indian democracy: whether the design of the Constitution can be a source of constitutional resilience against the rising threat of authoritarianism and Hindu majoritarianism. In India's Founding Moment, Khosla says that the constitutional vision underlying the Constitution has three components: "the explication of rules through codification; the existence of an overarching state; and representation centred on individuals" (4). But he does more than set out a history of these ideas in Indian constitutional thought. In addition, he makes three claims about the impact of these ideas on choices regarding the text and structure of the Constitution. Codification conceptualized the Constitution as an "instrument of political education" (22) that "was intended to create common meaning and explicate norms that other societies could take for granted" (21). A "centralized state" (22) would create a platform for a "common politics devoted to social and economic

\footnotetext{
1 Khosla 2019, 2020a, b, c; Khosla and Vaishnav 2021.
} 
transformation" (22) that would not be "captured by rigid social and cultural bonds and prejudices" (22) and free public policy from the grip of localism. India's system of political representation rejected the communal representation of the pre-Independence period under the Government of India Act, 1935 in favor of "a conception of citizenship that was free from the power of predefined identities" (22) and builds on "the affirmation of the individual" (23).

Of these three pillars of the constitutional vision of the Indian founders, I want to focus on federalism, because it evolved in a dramatically different manner than originally envisioned. Scholars of comparative federalism have long viewed India's federal arrangements as highly centralized, with K.C. Wheare famously terming them "quasi-federal." ${ }^{2}$ This assessment has been rooted in a number of features of the Constitution, including the power of Parliament through simple majority to alter state boundaries or create states, without the consent of the states involved; the supremacy of federal over state law in areas of concurrent jurisdiction, and the power of Parliament to legislate in areas of state jurisdiction (albeit subject to substantive and procedural checks); and the power of President's Rule under Article 356, which enables the central government to dismiss state governments, rule directly, and trigger new elections.

But the Constitution provides an incomplete picture of the original scheme of Indian federalism. A crucial decision of the Constituent Assembly was to reject drawing provincial boundaries on linguistic lines. Congress had been committed to linguistic provinces since the 1920 s, to enable politics in the vernacular. It abandoned this stance in the wake of the catastrophe of Partition, out of the fear that linguistic federalism would be the stepping stone to secession. This was a crucial implication of the centralized vision of federalism that Khosla describes. However, the rejection of linguistic province unraveled before Independence. In response to demands for a separate Telugu state, Andhra state was created out of Madras state in 1953, which in turn impelled the creation of the States Reorganization Commission. The Commission issued a series of specific recommendations that were largely based on language. In 1956, and again in 1960 and 1966, Parliament redrew state boundaries to create linguistic states across India. ${ }^{3}$

Linguistic federalism had profound implications for the structure of the Indian political party system and the rise of political competition. As Pradeep Chhibber and Rahul Verma have recently argued, India's party system has gone through four phases: first, Congress hegemony from Independence to 1967, with the only opposition coming from the socialist left and the Hindu nationalist right, neither credibly contending for power; second, the rise of political competition at the state level through new regional and caste-based political parties, leading to opposition victories in nine states, and prompting Indira Gandhi to delink state assembly and national elections from 1971 in order to preserve Congress rule at the center, which was largely successful; third, from 1989, which marked the end of majority governments at the center and the rise of coalition government, with the balance of power

\footnotetext{
2 Wheare (1963).

3 Choudhry (2009a, b); Choudhry (2016).
} 
held by caste-based and regional parties; and fourth, since 2014, the dominance of the Bhartiya Janata Party. ${ }^{4}$

Two forces contributed to the rise of new political parties, which challenged the Congress Party's hegemony first in the states and later at the center. First, linguistic federalism created new states which adopted regional languages as the official language of politics and public administration. New external state boundaries, in other words, led to the linguistic reconfiguration of internal state-level institutions, which in turn provided a hospitable environment for the rise of new regional parties built around recast state-level identities, especially in the South (e.g., Telugu Desam, Dravida Munnetra Kazhagam, and All-India Anna Dravida Munnetra Kazhagam) but also in the North (e.g., the National Conference in Kashmir and the Akali Dal).

Second, new caste-based parties arose in states in the Hindi heartland that had not been reorganized and were therefore untouched by linguistic reorganization, such as Bihar and Uttar Pradesh. After the 1967 elections, these parties formed governing coalitions under the umbrella of the Samyukta Vidhayak Dal. They later gave way to a multiplicity of parties, such as the Bahujan Samaj Party, the Rashtirya Janata Dal, and the Samajwadi Party. As Chhibber and Verma demonstrate, one of the main factors driving the rise of caste-based political parties was political mobilization on the basis of caste for the extension of reservations in public sector employment to the Other Backward Classes (OBCs). The Congress Party resisted implementing reservations for OBCs at the national level, whose elites then turned their efforts to the state level, with OBC led governments taking power in Bihar and Uttar Pradesh in 1967. The Congress Party responded by splitting, with the left-wing led by Indira Gandhi and pursuing broader poverty alleviation policies, in an attempt to outflank OBC elites. She also severed the link between state and national elections, in order to nationalize politics and diminish the electoral impact of opposition-controlled state governments. This strategy paid off for the Congress Party, with a massive victory in the 1971 elections.

The next chapter of this story came in 1975, when Indira Gandhi was found guilty of committing electoral fraud arising out of the 1971 election. Had it stood, Gandhi's conviction would have stripped her of a seat in Parliament and barred her from seeking election to Parliament for 6 years. The judgment threatened to end Gandhi's political career. Gandhi's first response was to declare a state of emergency within weeks of the handing down of the judgment, imprison opposition leaders and political opponents, restrict press freedom, suspend habeas corpus, and direct the Congress Party majority in Parliament to adopt the infamous 42nd amendment.

The Emergency was the gravest threat to constitutional democracy that India had ever seen and raised the fear that Gandhi would effectively become a dictator, albeit one who ruled through commanding successive electoral victories in a rigged political system. ${ }^{5}$ The Supreme Court pushed back, by striking down the 39th Amendment and firmly establishing that multi-party democracy was an element of the basic structure of the Indian Constitution. ${ }^{6}$ In addition, Gandhi was constitutionally

\footnotetext{
${ }^{4}$ Chhibber and Verma (2018).

5 Prakash (2019); Jaffrelot and Anil (2020).

${ }^{6}$ Indira Nehru Gandhi v. Raj Narain 1975.
} 
obliged to hold national elections in 1977, and shortly before doing so, ended the Emergency. She suffered a decisive, and surprising, defeat. At the time, academic observers explained Gandhi's loss in terms of popular revulsion against Gandhi's abuse of power and denial of civil liberties. ${ }^{7}$ But in fact, she was defeated by an unlikely coalition, bringing together right-wing parties with caste-based parties in the Hindi belt who were dissatisfied with the Congress Party's stance on OBCs. ${ }^{8}$

This is a highly simplified and stylized account of a complex story-more of an analytic narrative than history, let alone a history of ideas, as Khosla has provided. But it illustrates that Indian federalism, as a consequence of both its original structure and fundamental reform, provided institutional resources for the rise of new political parties, which challenged the Congress Party and saved India from constitutional disaster. Linguistic federalism led to the creation of regional political parties, who at first seized power at the state level from the Congress Party, and then contended for power at the center. Their coalition partners at the national level were caste-based parties in Bihar and Uttar Pradesh, led by OBC elites, who also first challenged Congress in states in the Hindi heartland whose borders were not changed by states reorganization, and then at the center. And so there is a relationship among democracy, federalism, political competition, and constitutional resilience that emerged under the Indian constitutional scheme, in a manner that was not part of the founding vision, and which in large part occurred in spite of it. States provided the political infrastructure for the rise of political parties that credibly contended for power and formed state governments, and from these bases became effective opposition parties nationally and competed for power at the center. They displaced Congress from 1989 to 1991, became coalition partners for Congress from 1991 to 1999, for the BJP from 1999 to 2004, and for Congress again from 2004 to 2014. And crucially, they saved India at its moment of greatest peril in 1977 by defeating Indira Gandhi at the polls.

What insights do these constitutional dynamics shed on India's Founding Moment? To the extent that Khosla, sotto voce, attributes the endurance the success of India's constitutional democracy to a set of initial choices and the ideas behind them, his argument needs to be qualified. One of basic goals of any constitution is to provide a framework for bounded, partisan, pluralist contestation among political parties that track and major economic and social cleavages of a political community, through regular, periodic elections with universal adult suffrage in which these parties complete for power. Political parties consider it to be to their mutual advantage to compete for power within a constitutional system, rather than stepping outside of it and seizing power through force or fraud. The process of institutionalized competition within which political conflict occurs does not undermine constitutional stability; rather, it reinforces it through iteration. ${ }^{9}$

Khosla does not discuss the place of political competition and multi-party democracy in pre-Independence Indian constitutional thought. As Aradhya Sethia accounts, those issues were debated in the Constituent Assembly on only a few

\footnotetext{
7 Rudolph and Rudolph 1977; Weiner 1977.

8 Brass 1981; Chhibber and Verma 2018.

9 Choudhry 2018; Choudhry 2019; Choudhry, unpublished.
} 
occasions, in relation to proposals for multi-party, power-sharing cabinets, and the constitutionalization of the office of the Leader of the Opposition. ${ }^{10}$ Both proposals were rejected. As well, Sethia identifies misgivings in Constituent Assembly about the partisan abuse of Article 356, on occasions where different political parties controlled the center and a state. But the idea of recognizing and regulating parties as institutions of constitutional government in order to preserve multi-party democracy and political competition was not discussed. And so the Constitution itself does not contain provisions on these issues at all.

Sethia attributes the silence of the Constituent Assembly, and of the Constitution itself, on political parties to three factors: (a) the Congress System of internal party democracy, which shifted political competition among parties to competition within the Congress Party among party factions and obviated the need to constitutionalize internal party democracy; (b) the fear of legitimizing communal parties, rooted in the experience of the provincial assembly elections in 1946 under the Government of India Act, 1935, when the Muslim League obtained sufficient support to take power in Punjab and Sind and push for Partition; and (c) anti-partyism, based on the concern that political parties would not govern in the broader public interest, and therefore should not be constitutionally entrenched.

The constitutional recognition and regulation of political parties can go beyond guaranteeing their status, to potentially conferring powers on them in relation to the electoral and legislative processes, and regulating their goals and activities (militant democracy) and internal governance (internal democracy). Underlying and uniting these particulars of constitutional design is the very notion of multi-party democracy itself as a constitutive element of any constitutional democracy. The likely reason for silence of the Constitution on this basic idea is the impact of Partition on India's nascent political party system. After Partition, the Muslim League withdrew from the Constituent Assembly, leaving the Congress Party with an overwhelming majority (approximately 275 out of 303 members). No doubt, Congress presupposed its ongoing political dominance through sustained electoral victories both centrally and in the states for the foreseeable future. It therefore neither saw the desirability of empowering potential competitors, nor the necessity of insuring itself against the possibility of future electoral losses - both of which might have led it to constitutionally entrench measures to protect multi-party democracy and political competition.

Indian federalism ended up fulfilling this function, through the medium of political parties. As I have previously argued, federalism may enhance political competition and multi-party democracy, because it multiplies the opportunities for electoral choice, by increasing the number of governments that must be democratically elected, and by creating different political majorities empowered to elect different governments. ${ }^{11}$ The proliferation of opportunities to wield power allows political parties that lose at the national level to win at the state level through the support of a different political majority. Moreover, states provide important political resources to parties that strengthen their ability to compete nationally. The possibility of wielding power enhances the ability of parties to recruit and train political elites. The

\footnotetext{
10 Sethia 2019.

11 Choudhry 2009a, b.
} 
expertise developed from political mobilization at the state level can be transferred to national elections. Finally, governing at the state level provides parties with the advantages of incumbency, such as greater public profile and the ability to shape public policy to enhance their base of political support.

In framing the constitution of a new democracy, protecting and promoting political competition in the service of constitutional resilience is a crucial goal. Political competition, let alone through federalism, was not part of the vison of the framers, as set out in India's Founding Moment. In this respect, the framers of the Indian constitution came up seriously short. The constitutional infrastructure for political competition arose through other means. One was the Supreme Court of India, under the influence of the German emigré Dieter Conrad, who foresaw the dangers of Congress Party dominance through the lens of the tragedy of Weimar. The Supreme Court used elements of Article 79(3) of the Grundgesetz to fashion the basic structure doctrine, which includes democracy, in Kesavananda Bharati v. State of Kerala. $^{12}$ The basic structure doctrine operates defensively, as a check on attempts to dismember or destroy constitutional democracy. However, it does not itself encourage political competition to occur. That role has been served by federalism, through constitutional politics subsequent to Independence-in part through the Constitution as originally designed, in part as a consequence of linguistic reorganization, which the framers opposed. And so much of the success of the Constitution happened in opposition to the animating ideas of the Indian founding.

As Modi concentrates power after two successive national electoral victories, the question is whether federalism can serve again as a source of constitutional resilience, by providing institutional resources for Modi's opponents to arrest India's slide into electoral authoritarianism. ${ }^{13}$ Yogendra Yadav has argued, for example, that the states should defer or undermine the implementation of the National Register of Citizens, because of the fear that Muslims excluded from it will not be able to claim citizenship through the CAA, whereas non-Muslims will. ${ }^{14}$ However, the equivalent of non-cooperation by state governments does not provide a structural solution to the BJP's growing electoral dominance, except as a tool for political mobilization. Modi's stunning decision to abrogate Kashmir's special autonomy, and to abolish Kashmir's status as a state and convert it into two union territories, is a sober reminder (putting to one side the distinct constitutional issues arising from Article 370) that Parliament has the unilateral power, unparalleled in other federations, to create, adjust the boundaries of, and abolish states. Indian federalism is remarkably constitutionally fragile. Indeed, it is worth remembering states reorganization occurred through simple majority votes in Parliament, without the need for state consent, which made it possible to occur.

Whether India continues on the path to electoral authoritarianism and Hindu majoritarianism remains unclear in the balance. India might be saved by an alliance between the Supreme Court and opposition-controlled states, mediated through the institutional mechanisms of state-level electoral process and court rulings protecting

\footnotetext{
12 Conrad 1970. For an intellectual history, see Noorani 2006, ch. 1.

13 Aiyar and Tillin 2020.

14 Yadav 2020.
} 
federalism and democracy under the basic structure doctrine. These mechanisms that evolved after India's founding to preserve its constitutional democracy. They fall outside and compromise the vision described so beautifully in India's Founding Vision. However, by protecting political competition, they preserve the very idea of India as a constitutional democracy.

Funding Open Access funding enabled and organized by Projekt DEAL.

\section{Declarations}

Conflict of interest The author declares no competing interests.

Open Access This article is licensed under a Creative Commons Attribution 4.0 International License, which permits use, sharing, adaptation, distribution and reproduction in any medium or format, as long as you give appropriate credit to the original author(s) and the source, provide a link to the Creative Commons licence, and indicate if changes were made. The images or other third party material in this article are included in the article's Creative Commons licence, unless indicated otherwise in a credit line to the material. If material is not included in the article's Creative Commons licence and your intended use is not permitted by statutory regulation or exceeds the permitted use, you will need to obtain permission directly from the copyright holder. To view a copy of this licence, visit http://creativecommons.org/licen ses/by/4.0/.

\section{References}

Aiyar Y, Tillin L (2020) One nation, BJP and the future of Indian federalism. Indian Review 19:117-135. https://doi.org/10.1080/14736489.2020.1744994

Brass PR (1981) Congress, the Lok Dal, and the Middle-Peasant Castes: An analysis of the 1977 and 1980 Parliamentary Elections in Uttar Pradesh. Pac Aff 54:5-41. https://doi.org/10.2307/2757709

Chhibber P, Verma R (2018) Ideology and identity: the changing party systems of India. Oxford University Press, Oxford. https://doi.org/10.1093/oso/9780190623876.001.0001

Choudhry S (2009a) Managing linguistic nationalism through constitutional design: lessons from South Asia. International Journal of Constitutional Law 7:577-618. https://doi.org/10.1093/icon/mop026

Choudhry S (2009) 'He had a mandate': the South African Constitutional Court and the African National Congress in a Dominant Party Democracy. Constitutional Court Review 2: 1-86. https://hdl.handle. net/10520/EJC28143.

Choudhry S (2016) Language. In: Choudhry S, Khosla M \& Mehta PB (eds), Oxford Handbook of the Indian Constitution. Oxford University Press, Oxford, pp 180-195. https://doi.org/10.1093/law/ 9780198704898.003.0011.

Choudhry S (2018) Will democracy die in darkness? Calling autocracy by its name. In: Graber M, Levinson S, Tushnet M (eds), Constitutional Democracies in Crisis?. Oxford University Press, New York, pp 571-584. https://doi.org/10.1093/law/9780190888985.001.0001

Choudhry S (2019) Resisting democratic backsliding: an essay on Weimar, self-enforcing constitutions, and the Frankfurt School. Global Constitutionalism 7:54-74. https://doi.org/10.1017/S204538171 8000011

Choudhry S (unpublished) Opposition Powers in Parliamentary Democracies.

Conrad D (1970) Limitation of amendment procedures and the constituent power. Indian Y.B. Int'1 Aff. 15-16: 347, 380.

Indira Nehru Gandhi v. Raj Narain, 1975 Supp SCC 1.

Jaffrelot C, Anil P (2020) India's first dictatorship: the emergency, 1975-1977. Oxford University Press, Oxford

Kesavananda Bharati v. State of Kerala, (1973) 4 SCC 225. 
Khosla M (2019) India's founding values are threatened by sinister new forms of oppression. The Guardian, 28 December 2019. https://www.theguardian.com/commentisfree/2019/dec/28/indias-foundingvalues-are-threatened-by-sinister-new-forms-of-oppression. Accessed 21 Dec 2021.

Khosla M (2020a) The battle for India's founding ideas. Time, 6 January 2020. https://time.com/57599 27/battle-indias-ideals/. Accessed 21 Dec 2021.

Khosla M (2020b) Who Is an Indian?. The Atlantic, 26 January 2020. https://www.theatlantic.com/inter national/archive/2020/01/india-republic-citizenship-law-muslim-hindu/605419/. Accessed 21 Dec 2021.

Khosla M (2020c) The Precarious Foundations of Indian Democracy. Foreign Affairs, 5 February 2020. https://www.foreignaffairs.com/articles/india/2020-02-05/precarious-foundations-indian-democ racy. Accessed 21 Dec 2021.

Khosla M, Vaishnav M (2021) The Three Faces of the Indian State, Journal of Democracy, January 2021.

Noorani AG (2006) Constitutional Questions and Citizens' Rights. Oxford University Press, Delhi

Prakash G (2019) Emergency Chronicles: Indira Gandhi and Democracy's Turning Point. Princeton, Princeton University Press

Rudolph LI, Rudolph SH (1977) India's election: backing into the future. Foreign Aff 55:836-853

Sethia A (2019) Where's the party? Towards a Constitutional Biography of Political Parties Indian Law Review 3:1-32. https://doi.org/10.1080/24730580.2019.1611179

Weiner M (1977) The 1977 Parliamentary Elections in India. Asian Affairs 17:619-626. https://doi.org/ $10.2307 / 2643409$

Wheare KC (1963) Federal Government, 4th edn. Oxford University Press, Oxford

Yadav Y (2020), States can checkmate Modi govt on NRC in 3 easy steps: delink, defer, diffuse ThePrint. in (18 March 2020). https://theprint.in/opinion/states-can-checkmate-modi-govt-on-nrc-in-3-easysteps-delink-defer-diffuse/378381/. Accessed 21 Dec 2021.

Publisher's Note Springer Nature remains neutral with regard to jurisdictional claims in published maps and institutional affiliations. 